
Not for reproduction, distribution or commercial use.

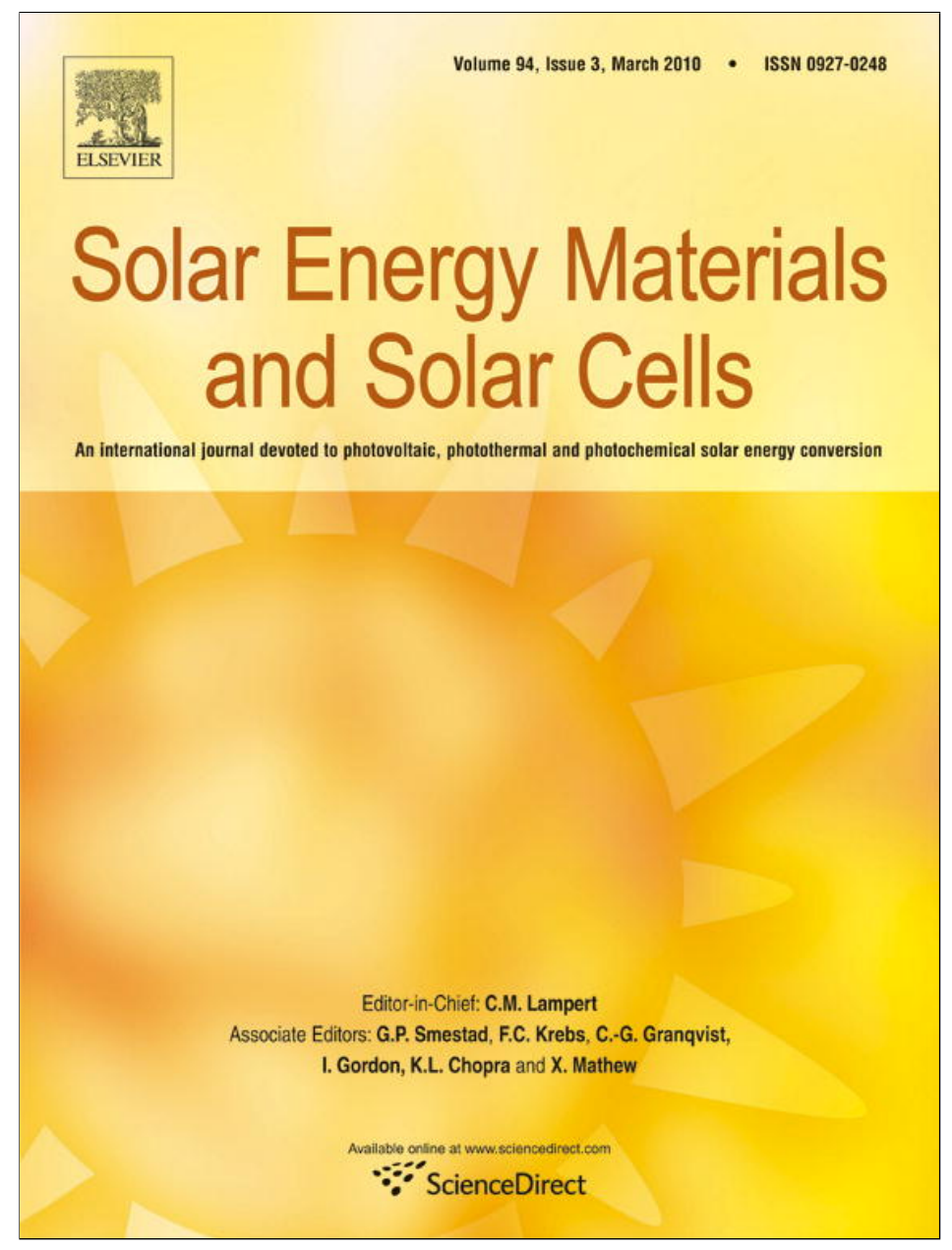

This article appeared in a journal published by Elsevier. The attached copy is furnished to the author for internal non-commercial research and education use, including for instruction at the authors institution and sharing with colleagues.

Other uses, including reproduction and distribution, or selling or licensing copies, or posting to personal, institutional or third party websites are prohibited.

In most cases authors are permitted to post their version of the article (e.g. in Word or Tex form) to their personal website or institutional repository. Authors requiring further information regarding Elsevier's archiving and manuscript policies are encouraged to visit:

http://www.elsevier.com/copyright 


\title{
Electrochemical, optical and X-ray absorption studies of Ce/V mixed oxides thin films
}

\author{
I. Kozjek Škofic ${ }^{\mathrm{a}, *}$, J. Padežnik Gomilšek ${ }^{\mathrm{b}}$, A. Kodre ${ }^{\mathrm{c}, \mathrm{d}}$, N. Bukovec ${ }^{\mathrm{a}}$ \\ a Faculty of Chemistry and Chemical Technology, Aškerčeva 5, SI-1000 Ljubljana, Slovenia \\ ${ }^{\mathrm{b}}$ Faculty of Mechanical Engineering, Smetanova 17, SI-2000 Maribor, Slovenia \\ ${ }^{\mathrm{c}}$ Faculty of Mathematics and Physics, Jadranska 19, SI-1000 Ljubljana, Slovenia \\ d J. Stefan Institute, Jamova 39, SI-1001 Ljubljana, Slovenia
}

\section{A R T I C L E I N F O}

\section{Article history:}

Received 24 September 2009

Accepted 20 November 2009

Available online 16 December 2009

Keywords:

Counter electrode

Cerium vanadium mixed oxide

Electrochemistry

Optical properties

X-ray absorption

\begin{abstract}
A B S T R A C T
$\mathrm{Ce} / \mathrm{V}$ mixed oxide thin films with molar ratio 1 were prepared by sol-gel method from $\mathrm{CeCl}_{3} \cdot 7 \mathrm{H}_{2} \mathrm{O}$ and $\mathrm{NH}_{4} \mathrm{VO}_{3}$ with methanol or distilled water as a solvent and dip-coated on $\mathrm{SnO}_{2} / \mathrm{F}$-covered glass. The electrochemical, optical and structural properties of thin films depend on the solvent and heat treatment. The ion-storage capacities of the films annealed at $500{ }^{\circ} \mathrm{C}$, prepared from methanol, $60 \mathrm{~nm}$ thick, was approximately $13 \mathrm{mC} \mathrm{cm}{ }^{-2}$ and those prepared with distilled water, $40 \mathrm{~nm}$ thick, more than $20 \mathrm{mC} \mathrm{cm}^{-2}$. The ion-storage capacity of the films annealed at $400{ }^{\circ} \mathrm{C}$ was approximately $1 \mathrm{mC} \mathrm{cm}-2$. $\mathrm{X}$-ray absorption fine structure analysis showed that crystallization process of $\mathrm{CeVO}_{4}$ occurs in temperature range between 400 and $500{ }^{\circ} \mathrm{C}$.
\end{abstract}

(c) 2009 Elsevier B.V. All rights reserved.

\section{Introduction}

Vanadium $(\mathrm{V})$ oxide is one of the most investigated materials for its use as a counter-electrode in electrochromic devices. Its charge capacity is appropriate to serve as ion-storage film, but other electrochromic characteristics are suboptimal. To improve these deficiencies mixed oxides of several elements ( $\mathrm{W}, \mathrm{Mo}, \mathrm{Ti}, \mathrm{Ce}$, $\mathrm{Cu}, \mathrm{Ni}, \mathrm{Cr}, \mathrm{Nb}$ ) with $\mathrm{V}_{2} \mathrm{O}_{5}$ were studied [1-8].

Among the most studied mixed oxide is $\mathrm{Ce} / \mathrm{V}$ mixed oxide. $\mathrm{CeO}_{2}$ alone exhibits good transparency in reduced and oxidized states in the visible region, it shows strong absorption of light below $380 \mathrm{~nm}$ and good reversibility of lithium intercalation. However, its charge capacity is too low for a counter-electrode in electrochromic devices. On the other hand the charge capacity of the $\mathrm{V}_{2} \mathrm{O}_{5}$ is appropriate for use as a counter-electrode, but during the lithium intercalation an unfavourable brownish-grey coloration occurs. The $\mathrm{Ce} / \mathrm{V}$ mixed oxide might combine excellent properties of both oxides. Several methods were applied to prepare mixed $\mathrm{Ce} / \mathrm{V}$ oxides: reactive r.f. sputtering, electrolysis, pulsed laser ablation and sol-gel [9-12].

Sol-gel processing has many advantages over other techniques. A high degree of homogeneity of the thin films can be attained on the molecular level, a variety of dopants can be added to the initial sol and different molar ratios of the oxides can be

\footnotetext{
* Corresponding author. Tel.: +38612419 154; fax: +38612419220.

E-mail address: irena.kozjek-skofic@fkkt.uni-lj.si (I. Kozjek Škofic).
}

achieved with the purpose of improvement of the structural, electrochemical and optical properties.

Two different sol-gel routes are used in general: metal salts in aqueous solutions or metal alkoxides in organic solvents. Crnjak Orel et al. [13] reported on the preparation of aqueous sols from $\mathrm{V}_{2} \mathrm{O}_{5}$ and $\mathrm{Ce}\left(\mathrm{NH}_{4}\right)_{2}\left(\mathrm{NO}_{3}\right)_{6}$. Opara Krašovec et al. [12] prepared Ce/ $\mathrm{V}$ sols from $\mathrm{CeCl}_{3} \cdot 7 \mathrm{H}_{2} \mathrm{O}$ and citric acid in a proportion $1: 2$ then added $\mathrm{V}$-oxoisopropoxide in various ratios and dissolved the mixture in ethanol. V-alkoxides are quite expensive and sensitive to the moisture, so they were replaced with $\mathrm{NH}_{4} \mathrm{VO}_{3}$. In this case the synthesis of sols was limited by the solubility of the $\mathrm{NH}_{4} \mathrm{VO}_{3}$ in the mixture of ethanol and citric acid and only sols with $\mathrm{Ce} / \mathrm{V}$ molar ratio $>1$ could be prepared [4]. In previous papers $[4,14,15]$ we reported the influence of the annealing process on the properties of the mixed oxide $\mathrm{Ce} / \mathrm{V}$ thin film. With a careful selection of atmosphere, temperature and duration of the heat treatment the ion-storage capacities and the reversibility of the redox process were improved. The thin films annealed in argon were found superior to thin films annealed in air. The thickness of all prepared thin films was less than $60 \mathrm{~nm}$, so the X-ray diffraction (XRD) analysis yielded only substrate peaks. X-ray absorption fine structure (XAFS) provided information on the oxidation number and the local structure around the constituent metal ions [16,17]. The aim of our subsequent investigation was to modify the basic synthesis in order to decrease the Ce/V molar ratio. In this paper, we report on the mixed oxides $\mathrm{Ce} / \mathrm{V}=1$ coatings prepared by sol-gel technique. 


\section{Experimental}

$\mathrm{Ce} / \mathrm{V}$ sols with a molar ratio of about 2 can be prepared by dissolving $\mathrm{CeCl}_{3} \cdot 7 \mathrm{H}_{2} \mathrm{O}$ and $\mathrm{NH}_{4} \mathrm{VO}_{3}$ in a mixture of citric acid and ethanol [4]. The reduction of the $\mathrm{Ce} / \mathrm{V}$ molar ratio is limited with the solubility of $\mathrm{NH}_{4} \mathrm{VO}_{3}$ in ethanol. A gel forms before the reaction mixture is dissolved. To avoid this process the $\mathrm{Ce} / \mathrm{V}$ sols was mixed from inorganic precursors $\mathrm{CeCl}_{3} \cdot 7 \mathrm{H}_{2} \mathrm{O}$ and $\mathrm{NH}_{4} \mathrm{VO}_{3}$ dissolved in a mixture of citric acid and methanol or distilled water. When the sols with a molar ratio 1 were prepared in methanol, the reaction had to be carried in a thermostatic room under anhydrous conditions to prevent the hydrolysis to proceed too fast and the formation of gel to form before the reaction mixture of $\mathrm{CeCl}_{3} \cdot 7 \mathrm{H}_{2} \mathrm{O}, \mathrm{NH}_{4} \mathrm{VO}_{3}$ and citric acid in methanol was dissolved. The sols were clear dark blue and were stable for a few days in a refrigerator. When distilled water was used as a solvent, the mixture was dissolved quite fast, but the formation of the sol was finished after two days, as state the colour of the sol showed. The sol was very stable, without changing colour; no gelation was observed even after two months at room temperature. The films were deposited by dip-coating technique on a transparent glass with a conductive coating of fluorine-doped tin dioxide (Pilkington, K-glass, $R_{\square}=13 \Omega \square^{-1}$ ). The plates were previously cleaned with ethanol in an ultrasonic cleaner, washed with distilled water and dried in air at room temperature. For the thin films prepared from $\mathrm{H}_{2} \mathrm{O}$ prior to dip-coating, the substrates were dipped into a wetting agent ( $1 \mathrm{wt} \%$ of Etolat TD-60 in ethanol) and left to dry in air. The films, all with $\mathrm{Ce} / \mathrm{V}=1$, were prepared by a single dip with pulling velocity of $10 \mathrm{~cm} / \mathrm{min}$. Higher speed resulted in a thicker film. After pulling, the films were dried in air and then annealed at 400 and $500{ }^{\circ} \mathrm{C}$ in air for $20 \mathrm{~min}$. They exhibited good adhesion to the glass substrate. In the following discussion, the films prepared with methanol will be denoted by (a), and those prepared with distilled water, by (b).

Thermogravimetric (TG) measurements of the thin films, deposited on $\mathrm{Al}$ foil, were carried out using a Mettler Toledo TA/ SDTA $851^{\mathrm{e}}$ thermoanalyser in the temperature range between 25 and $600{ }^{\circ} \mathrm{C}$. Air flow rate was $100 \mathrm{~mL} / \mathrm{min}$ and the heating rate was $5 \mathrm{~K} / \mathrm{min}$. Platinum crucibles were used. The base line was subtracted in all cases.

Electrochemical measurements were performed using an EG\&G PAR273 computer-controlled potentiostat-galvanostat consisting of a three electrode cell, filled with $80 \mathrm{~mL}$ of $1 \mathrm{M} \mathrm{LiClO}_{4}$ in propylene carbonate (PC). The working electrode was a $\mathrm{Ce} / \mathrm{V}=1$ mixed oxide thin film deposited on $\mathrm{SnO}_{2} / \mathrm{F}$-coated glass with a surface area of $1 \mathrm{~cm}^{2}$. The reference electrode was $\mathrm{Ag} / \mathrm{AgCl}$ filled with a mixture of $1 \mathrm{M} \mathrm{LiCl}$ in methanol and $1 \mathrm{M} \mathrm{LiClO}_{4}$ in $\mathrm{PC}$ with a molar ratio 1:9. A platinum electrode served as a counterelectrode. Cyclic voltammetry (CV) was performed at potentials between +1.6 and $-1.6 \mathrm{~V}$ at the scan rate $50 \mathrm{mV} / \mathrm{s}$. Chronocoulometric (CPC) measurements were made at potentials -1.6 and $+1.6 \mathrm{~V}$ for $100 \mathrm{~s}$.

The optical transmittance characteristics of the Ce/V=1 mixed oxide thin films (b) in the $350<\lambda<1100 \mathrm{~nm}$ wavelength range were measured during the electrochemical reaction using a Perkin Elmer Lambda2 spectrometer connected to the potentiostatgalvanostat mentioned above. A homemade spectroelectrochemical transmission cell, filled with $40 \mathrm{~mL}$ of $1 \mathrm{M} \mathrm{LiClO}_{4}$ in $\mathrm{PC}$ was used. A potential scan rate of $50 \mathrm{mV} / \mathrm{s}$ was used for $\mathrm{CV}$ measurements. For background measurements, a cell filled only with electrolyte was used.

Field emission scanning microscope (Zeiss Supra $35 \mathrm{VP}$ ) equipped with energy dispersive spectroscopy Inca 400 (Oxford Instruments) was used to study the surface of the thin films deposited on $\mathrm{SnO}_{2} / \mathrm{F}$-covered glass and to determine their thickness.
Standard cerium $\mathrm{L}_{3}$ edge XAFS (X-ray absorption fine structure) spectra $\left(E_{\mathrm{L}_{3}}=5723 \mathrm{eV}\right)$ of films prepared with $\mathrm{H}_{2} \mathrm{O}$ and annealed to 400 and $500{ }^{\circ} \mathrm{C}$ were measured at the E4 experimental station of Hasylab at DESY, Hamburg. To reduce absorption in the support material, films were prepared on $10 \mu \mathrm{m}$ aluminium foil instead of glass. A stack of 8 foils provided $L_{3}$ edge jump of 0.1 , while vanadium K-edge signal $\left(E_{\mathrm{K}}=5465 \mathrm{eV}\right)$ was too low to record. A further increase in number of foils would not be reasonable because of the higher noise/signal ratio due to increase in the total absorption of the sample. Powder samples of $\mathrm{CeO}_{2}$ and $\mathrm{CeVO}_{4}$ on multiple layers of adhesive tapes were measured as standards. Energy calibration was established by simultaneous measurement of $\mathrm{Cr}$ foil $\left(E_{\mathrm{K}}=5989 \mathrm{eV}\right)$ in the posterior position. The spectra were analysed with Ifeffit program package $[18,19]$.

\section{Results and discussion}

TG measurements of thin films were used to determine the appropriate annealing temperatures. Fig. 1 shows that the decomposition of films prepared either with methanol (a) or distilled water (b) were similar over the entire temperature range. A minor difference between the TG curves appeared only in the initial stage, where the evaporation of the solvent occurred. The isothermal TG curve of thin film (a) showed that the final mass loss was achieved just before the temperature reached $500{ }^{\circ} \mathrm{C}$. The final mass loss for thin film (b) occurred after a few minutes at $500{ }^{\circ} \mathrm{C}$. According to these measurements, thin films with $\mathrm{Ce} / \mathrm{V}=1$ were annealed at $500{ }^{\circ} \mathrm{C}$ for 20 minutes. Some of the thin films were annealed at $400{ }^{\circ} \mathrm{C}$ to compare their structure and electrochemical properties to the films heat-treated at $500{ }^{\circ} \mathrm{C}$ and also to those annealed at $400{ }^{\circ} \mathrm{C}$ published in the literature [12]. Their current densities were lower by about $75 \%$ in comparison with the same films annealed at $500{ }^{\circ} \mathrm{C}$. The ionstorage capacities do not exceed value of $1 \mathrm{mC} \mathrm{cm}^{-2}$.

Cyclic voltammograms of the thin films (a) and (b) heattreated at $500{ }^{\circ} \mathrm{C}$ are presented in Fig. 2. X-ray absorption studies showed that cerium is in the lower $(3+)$ oxidation state so we assumed that the principal electrochemical activities arise from vanadium redox processes. During the first 50 cycles the charge exchanged increased because of the activation process. The same effect was also reported for some other vanadates [20]. Two distinct electrochemically active regions appeared: the first at potentials between 1.6 and $-0.3 \mathrm{~V}$ and the second between -0.9 and $-1.6 \mathrm{~V}$. In the first region two cathodic peaks were positioned

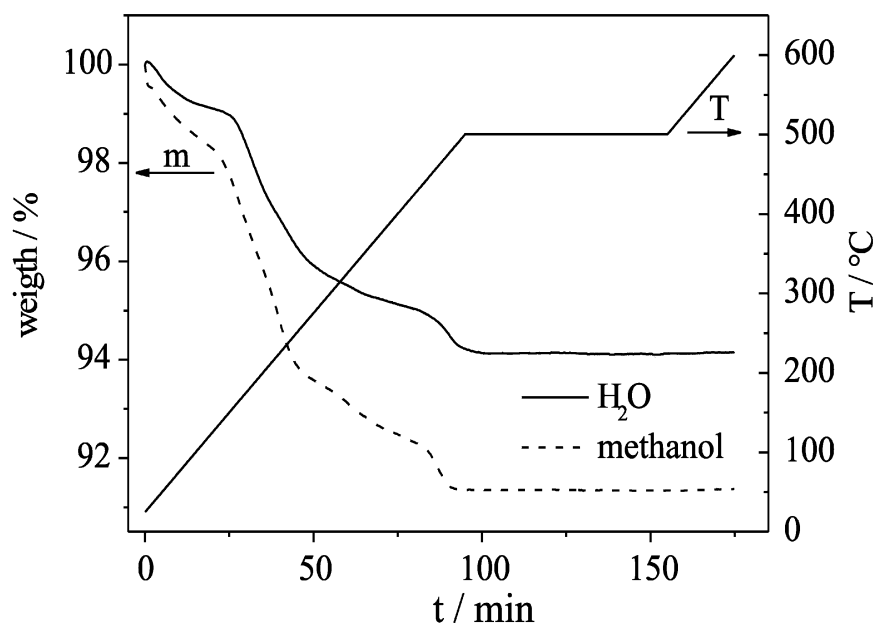

Fig. 1. Isothermal TG curves of the mixed oxide thin films at $500{ }^{\circ} \mathrm{C}$. The heating rate was $5 \mathrm{~K} \mathrm{~min}^{-1}$. 


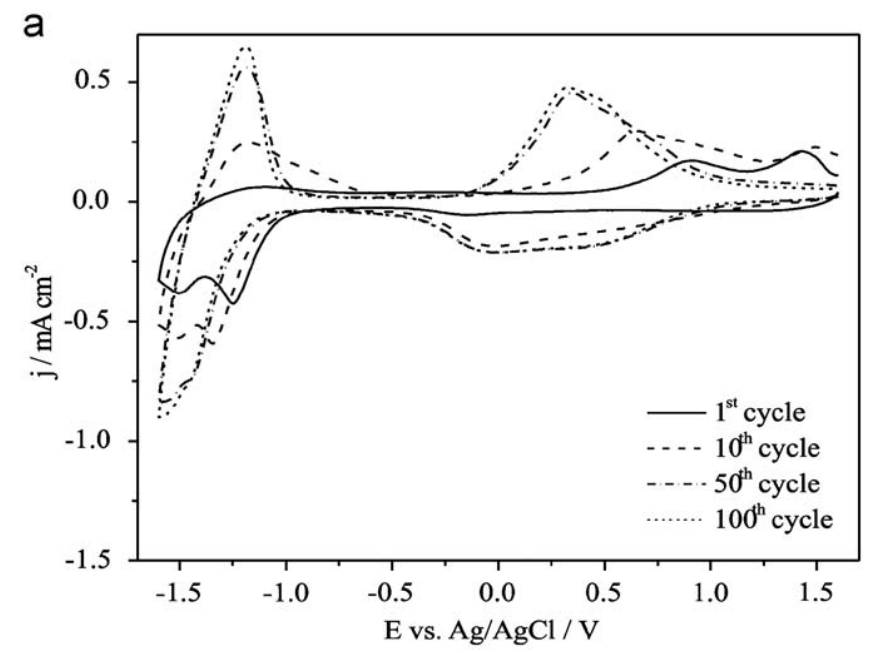

b

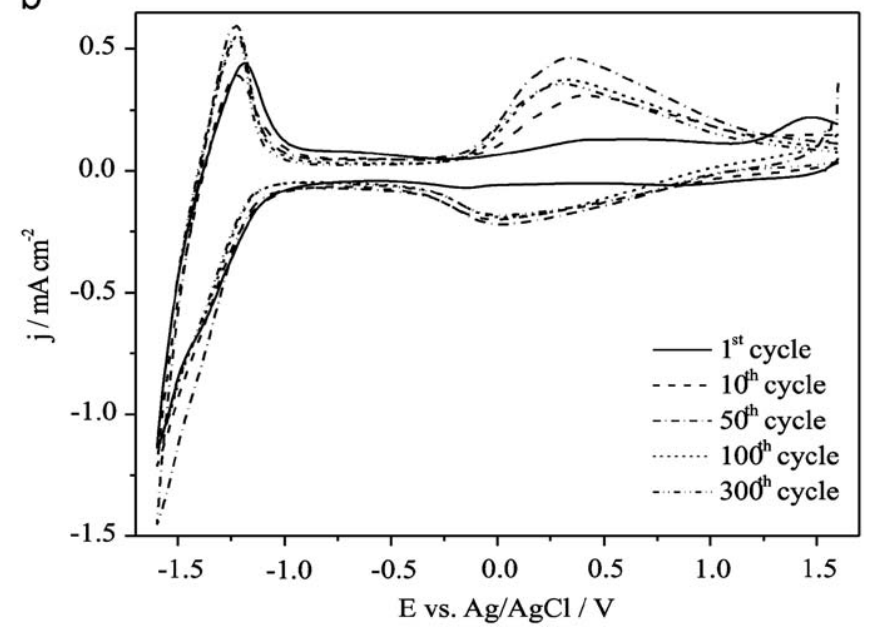

Fig. 2. Cyclovoltammograms of mixed oxide thin films (a) and (b) at scan rate $50 \mathrm{mV} / \mathrm{s}$.

in the first cycle at potentials of 1.25 and $-0.1 \mathrm{~V}$ and two anodic peaks at potentials of 0.9 and $1.4 \mathrm{~V}$. During cycling both cathodic peaks increased and shifted to $0.0 \mathrm{~V}$. The anodic peak at $0.9 \mathrm{~V}$ shifted to $0.3 \mathrm{~V}$ and the second one shifted outside the cycling area. According to the literature, these peaks are correlated to $\mathrm{V}^{5+} / \mathrm{V}^{4+}$ redox process [21]. Between -0.9 and $-1.6 \mathrm{~V}$ two cathodic and one anodic peak were also observed. These peaks resulted from the redox process of the lower states of vanadium $\left(\mathrm{V}^{4+} / \mathrm{V}^{3+}\right)$. The shape of the CVs of the thin film prepared with distilled water (b) is quite different from the CVs of thin film (a). Only one cathodic $(0.0 \mathrm{~V})$ and two anodic current peaks $(\sim-1.2$ and $0.4 \mathrm{~V}$ ) were observed. The cathodic peak was enlarged and shifted from $-0.1 \mathrm{~V}$ in the first cycle to $0.0 \mathrm{~V}$ at the 10 th. The increasing current density at potentials lower than $-1.1 \mathrm{~V}$ was connected to reduction of $\mathrm{V}^{4+}$. All anodic peaks were increased during cycling. The peak at $-1.25 \mathrm{~V}$ stayed at the same position, whereas the peak at $0.5 \mathrm{~V}$ shifted to a less positive potential. The ion-storage capacity $\left(Q_{i}\right.$ and $\left.Q_{e}\right)$ for both thin films was determined from CPC measurements by charging the thin films at limiting potentials of -1.6 and $+1.6 \mathrm{~V}$ vs. $\mathrm{Ag} / \mathrm{AgCl}$ for $100 \mathrm{~s}$ (Fig. 3). The shape of the CPC curves also showed the difference between the two thin films. For thin film (a), the maximum value of inserted charge was attained after $25 \mathrm{~s}$. The slope of the curve increased and the speed of the insertion of lithium ions improved with increasing number of cycles. The amount of inserted charge
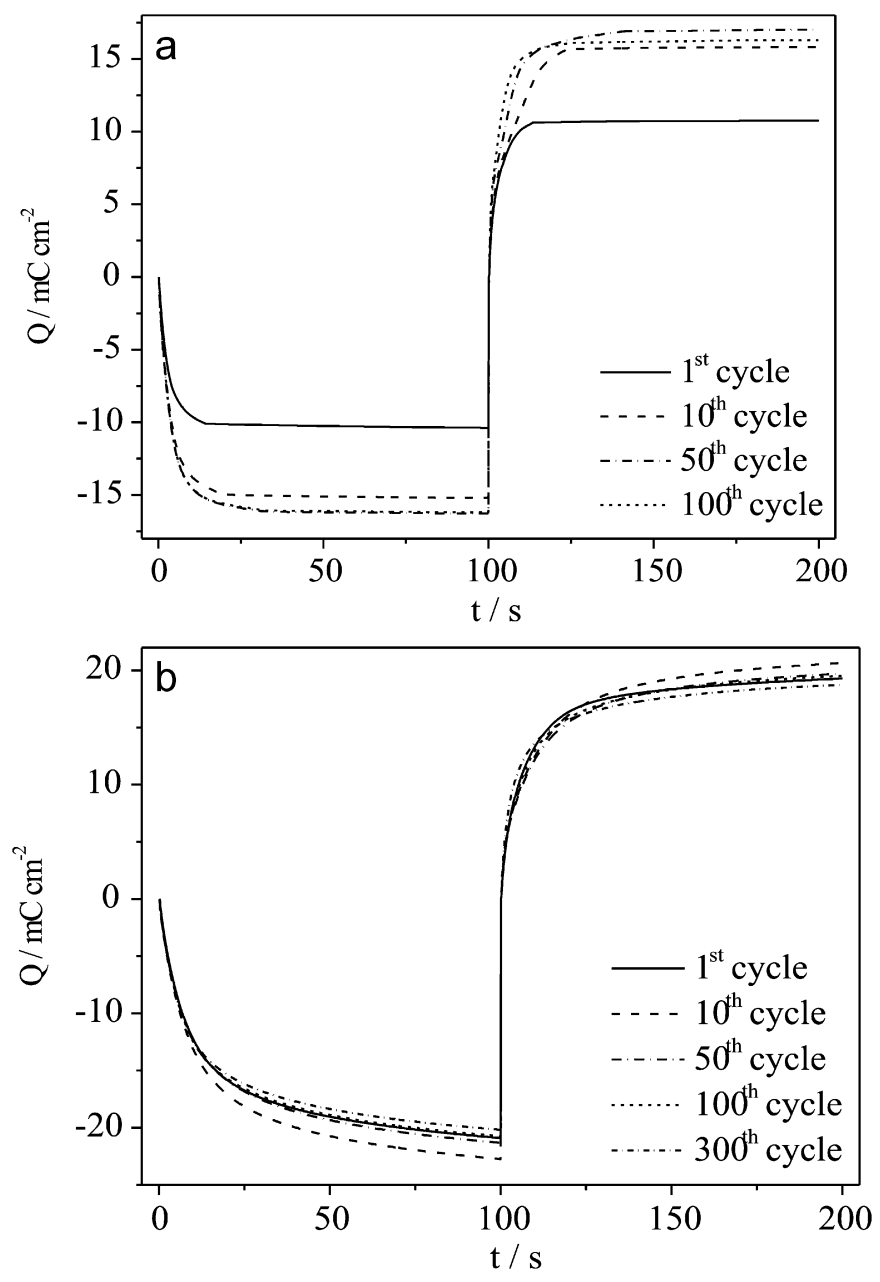

Fig. 3. Chronocoulometric curves of mixed oxide thin films (a) and (b) at potentials -1.6 and $+1.6 \mathrm{~V}$. Measurement time: $100 \mathrm{~s}$.

increased during the first 50 cycles, then remained stable. The maximum value of inserted $\mathrm{Li}^{+}$ions was about $8 \mathrm{mC} \mathrm{cm}^{-2}$ in the first cycle and increased up to $13 \mathrm{mC} \mathrm{cm}^{-2}$ in the 10 th cycle, then remained stable. The amount of inserted charge in the thin film (b) was greater than for thin film (a) and increased from approximately $21 \mathrm{mC} \mathrm{cm}^{-2}$ in the first cycle to 22.7 in the 10th cycle and then decreased to $20.7 \mathrm{mC} \mathrm{cm}^{-2}$ until the 100th cycle, then remained stable for the next 200 cycles. The reversibility of the inserted and extracted charge was between 0.92 and 0.94 for 300 cycles.

There was no difference in stoichiometry between the two prepared thin films. To explain the differences found in electrochemical studies of the films, scanning electron spectroscopy (SEM) was applied. The thickness of the films (a) was between 50 and $60 \mathrm{~nm}$ and film (b) about $40 \mathrm{~nm}$. SEM images of the surface showed that the surface of film (a) was more closed and smoother in comparison to film (b), where the structure of surface was more open and irregular (Fig. 4).

The electrochemical investigations showed that the ionstorage capacity of thin films (a) was too small for use as a counter-electrode, so no further structural, electrochemical and optical investigations were made on them.

We investigated the influence of the electrolyte concentration on the ion-storage capacity of the thin film prepared from $\mathrm{H}_{2} \mathrm{O}$ (Fig. 5). The first cycle differed from the subsequent cycles by the rather small current peak at $-1.3 \mathrm{~V}$. With increasing electrolyte concentration the current peaks were shifted to more positive 

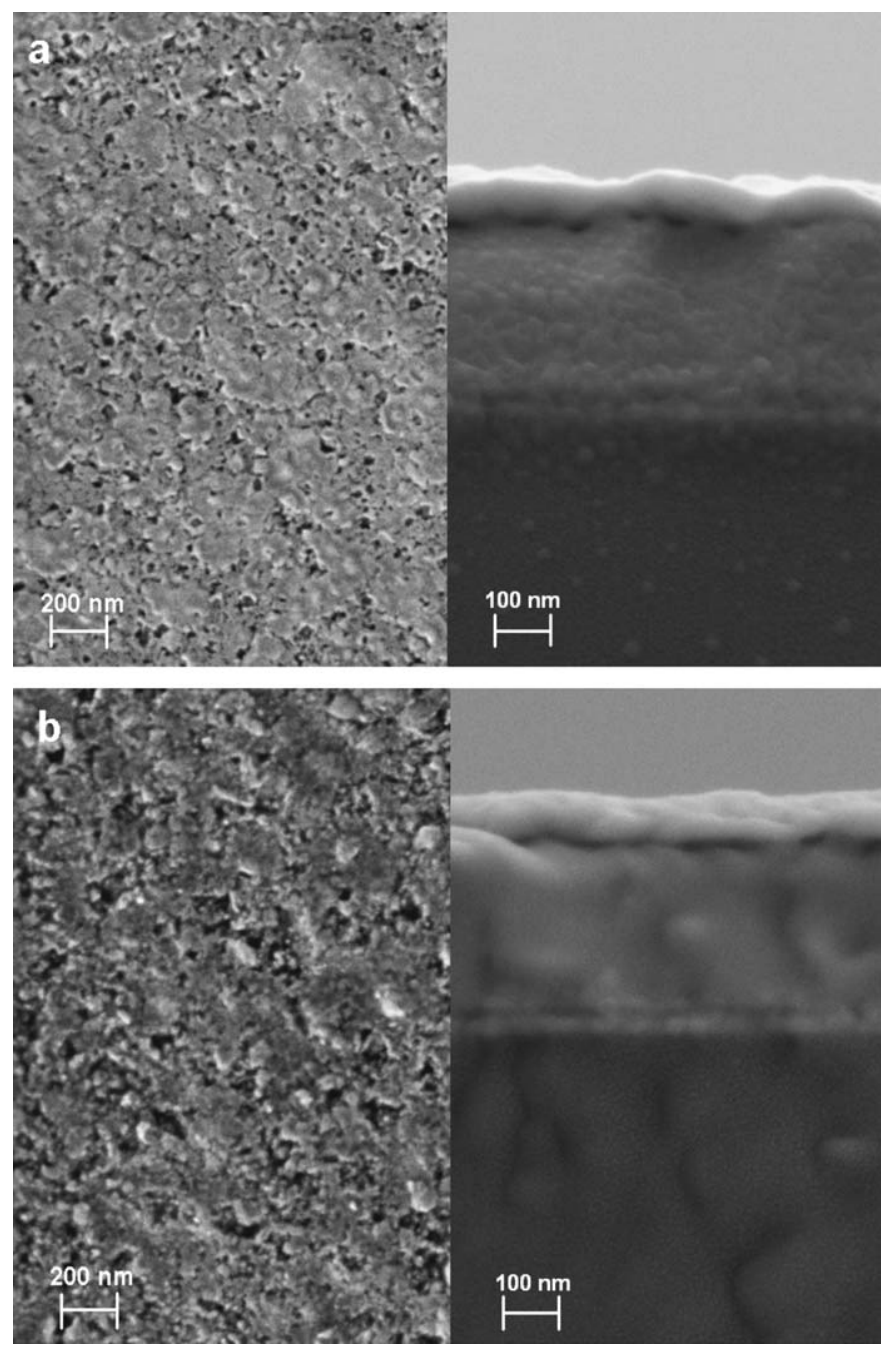

Fig. 4. SEM images of the surface of the thin film (A) and (B) (on the left side) and cross-sectional micrographs of both thin films (on the right side). The bottom layer is a glass substrate, the middle one is a conducting $\mathrm{SnO}_{2} / \mathrm{F}$ layer and the upper is the deposited thin film.

values of potential. A new current peak appeared at approximately $-1.4 \mathrm{~V}$ in 1.0 or $1.5 \mathrm{M}$ electrolyte. CPCs confirmed that an electrolyte concentration above $0.5 \mathrm{M}$ of $\mathrm{LiClO}_{4}$ in the PC was sufficient to assure enough $\mathrm{Li}^{+}$ions for the electrochemical reaction in the thin films.

A change in colour of the thin films (b) was recorded by in situ UV-vis transmittance measurements in the wavelength range from 350 to $1100 \mathrm{~nm}$ during the electrochemical charge/discharge cycles (Fig. 6). The results showed that the film was transparent over the whole visible range $(T>80 \%)$. The transmittance changed during charging by less than $2 \%$ with the exception of shorter wavelengths $(\lambda<470 \mathrm{~nm})$, where the transmittance increased by about $40 \%$.

The responses of the thin films were measured at $400 \mathrm{~nm}$ where the change of the optical transmittance as a function of the applied potential was considerable (Fig. 7). The major cathodic bleaching was observed between 1.6 and $-0.25 \mathrm{~V}(\sim 12 \%)$ where the current peaks could be attributed to change of the vanadium oxidation state $\left(\mathrm{V}^{5+} / \mathrm{V}^{4+}\right)$. At more negative potentials the monochromatic spectral transmittance changed during reduction of $\mathrm{V}^{4+}$ by approximately $2 \%$ and when the potential was swept up, the bleaching persisted until the potential reached $0.0 \mathrm{~V}[21]$. Then the transmittance decreased almost to the initial
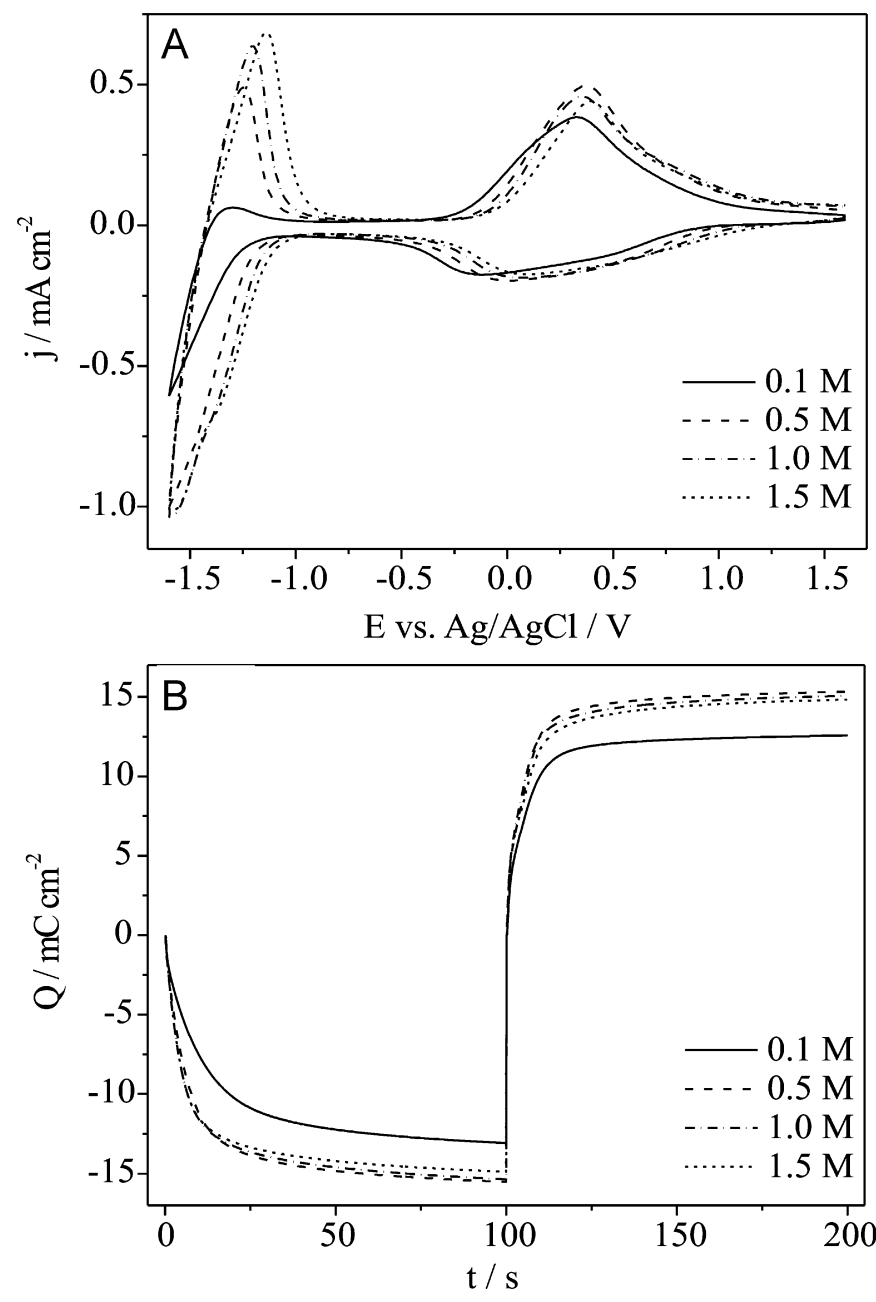

Fig. 5. Cyclovoltammograms (A) and chronocoulometric curves (B) of the thin film (b) according to concentration of the electrolyte. Scan rate: $50 \mathrm{mV} / \mathrm{s}$ for (A), time of measurement: $100 \mathrm{~s}$ for (B).

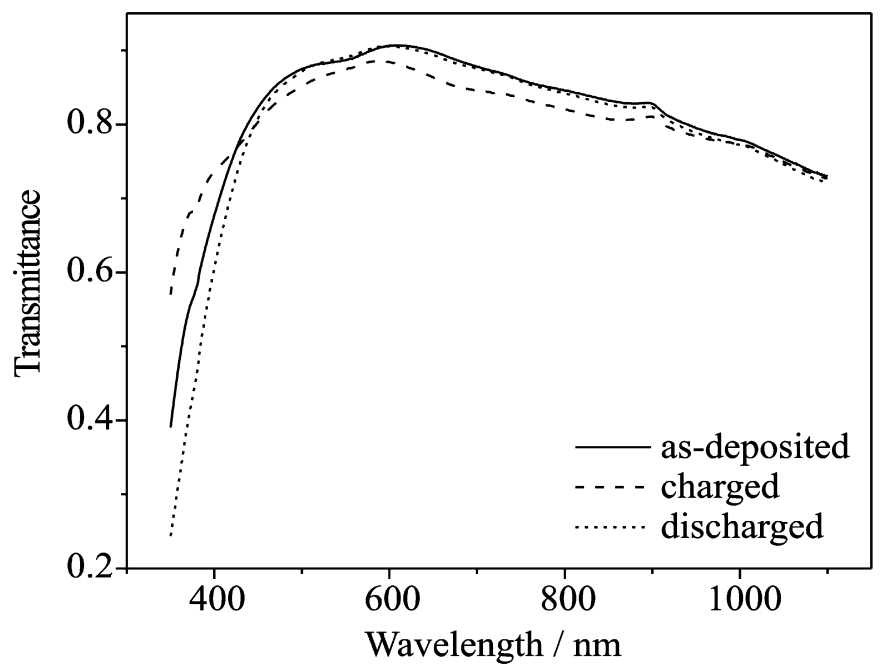

Fig. 6. Transmittance (UV-vis) of thin film (b) as deposited, charged and discharged after 300 cycles.

value. It can be seen that the spectroelectrochemical response depends on the potential range.

In X-ray absorption spectra, the oxidation number of the target element is reflected in the position and the shape 


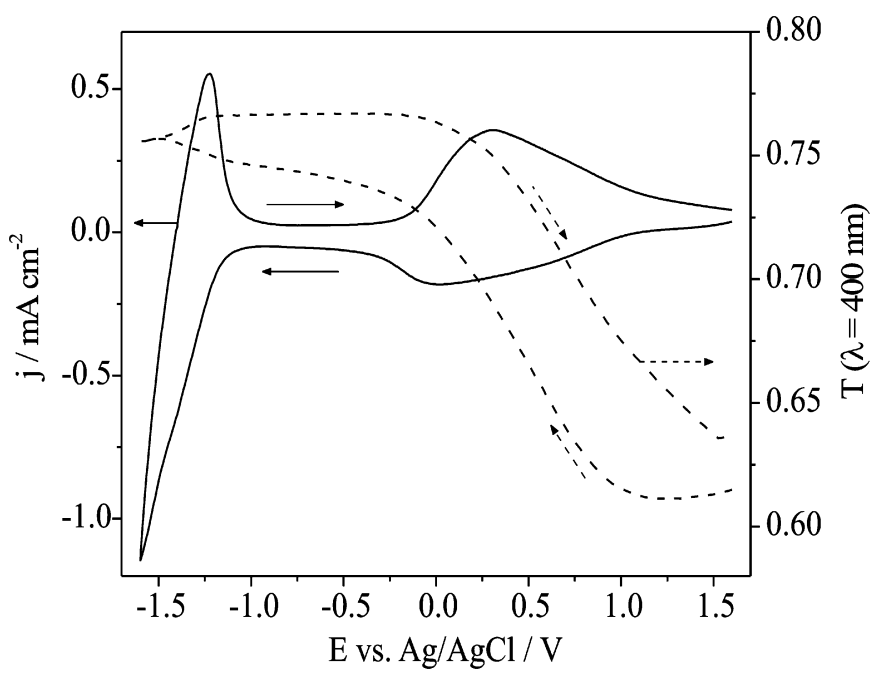

Fig. 7. Observed spectral monochromatic changes at $400 \mathrm{~nm}$ and corresponding cyclovoltammetric response at scan rate $50 \mathrm{mV} / \mathrm{s}$ for thin film (b).

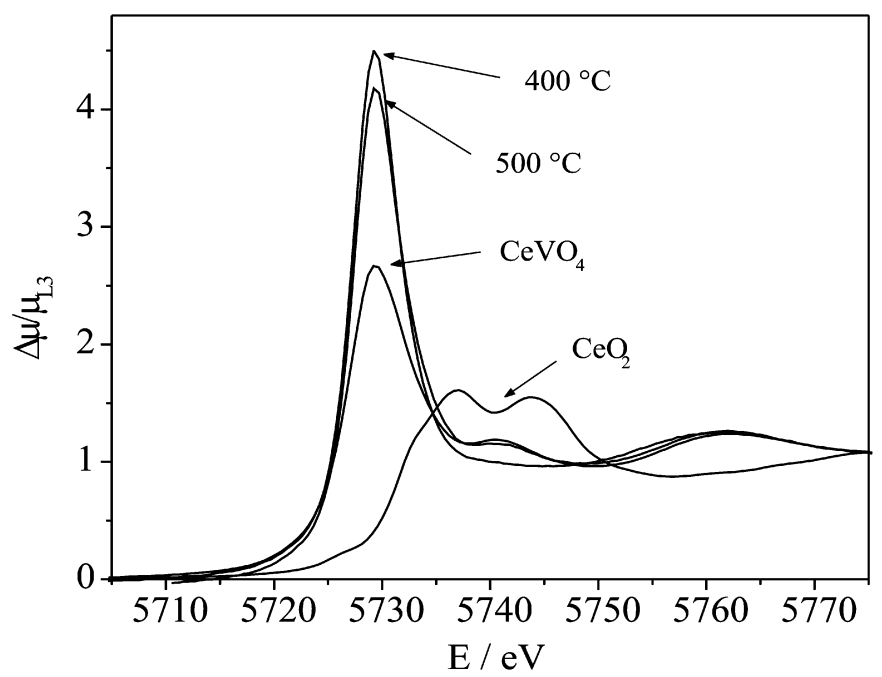

Fig. 8. Ce $\mathrm{L}_{3}$ edge profiles of films $(\mathrm{b})\left(400,500{ }^{\circ} \mathrm{C}\right)$ and $\mathrm{CeVO}_{4}, \mathrm{CeO}_{2}$ standards.

of the absorption edge. Fig. 8 reveals a strong similarity between the $\mathrm{Ce}_{3}$ edge in the two thin films and the standard $\mathrm{CeVO}_{4}$, pointing to cerium being in oxidation state +3 and excluding the admixture of $\mathrm{Ce}^{4+}$, exemplified by the $\mathrm{CeO}_{2}$ edge in the graph.

Since the $\mathrm{Ce}_{2} \mathrm{~L}_{3}$ edge is sandwiched between the $\mathrm{V}$ K edge and the Ce $\mathrm{L}_{2}$ edge, only limited information can be gained from $\mathrm{Ce}_{3}$ EXAFS (extended X-ray absorption fine structure) analysis: (i) the admixture of the signal from the close lying vanadium $K$ edge cannot be eliminated $\left(E_{\mathrm{CeL}_{3}}-E_{\mathrm{VK}}=258 \mathrm{eV}\right.$, i.e. $\left.k=8.2 \mathrm{~A}^{-1}\right)$; (ii) the range of the signal is very short due to the proximity of the Ce $\mathrm{L}_{2}$ edge $\left(E_{\mathrm{CeL}_{2}}-E_{\mathrm{CeL}_{3}}=438 \mathrm{eV}\right.$, i.e. $\left.k=10.7 \mathrm{~A}^{-1}\right)$; (iii) the $2 \mathrm{p}_{3 / 2} 4 \mathrm{~d} \rightarrow 5 \mathrm{~d}^{2}$ double-electron transition contributes a strong non-structural admixture to the signal at $k \sim 6 \mathrm{~A}^{-1}$. While there is no remedy for points (i) and (ii), the double-electron contribution can be eliminated by the procedure described in [16,17] since the double-electron excitation is an intra-atomic effect, dependent on the ion charge but largely independent of the chemical surroundings of the atom. An estimate of the contribution in Eor $k$-space may be extracted from the absorption spectra of suitable $\mathrm{Ce}^{3+}$ compounds with known structure. When the estimate is subtracted from the measured thin film absorption, practically pure structural signals for EXAFS analysis are obtained.

The spectra are shown in Fig. 9. The EXAFS signal of the films basically followed the oscillations of the $\mathrm{CeVO}_{4}$ standard but the effect of the annealing temperature was evident: the oscillations in the $400{ }^{\circ} \mathrm{C}$ sample annealed at lower temperature were more strongly damped than in the $500{ }^{\circ} \mathrm{C}$ sample or $\mathrm{CeVO}_{4}$ (Fig. 9a).

Due to the short $k$-space range available for the analysis, only the parameters of the first-neighbour shell could be determined. The starting model for the relaxation of parameters was built from crystallographic data on $\mathrm{CeVO}_{4}$ (tetragonal cell I 41/a m d [22] with $4+4$ oxygen atoms at 2.42 and $2.52 \AA$ ). Since no change in the oxidation state of the Ce ion was observed in XANES (Fig. 9), vacancies in the first shell of neighbours were not expected. The parameters defining the number of oxygen neighbours were therefore kept fixed at the model values while the two Ce-O distances and the width of their distribution were varied (Table 1). Relatively good agreement with the model was found for both films. The main difference between the samples was in the distribution widths $\sigma^{2}$, i.e. in the degree of static disorder. The value $0.013(3) \AA^{2}$ was obtained both for the $\mathrm{CeVO}_{4}$ standard and the $500{ }^{\circ} \mathrm{C}$ film, and $0.017(3) \AA^{2}$ for the $400{ }^{\circ} \mathrm{C}$ film. The effect is seen in Fig. 9b in the lower amplitude of the $400{ }^{\circ} \mathrm{C}$ peak in Fourier transform at $2 \AA$. It can be concluded that the intense
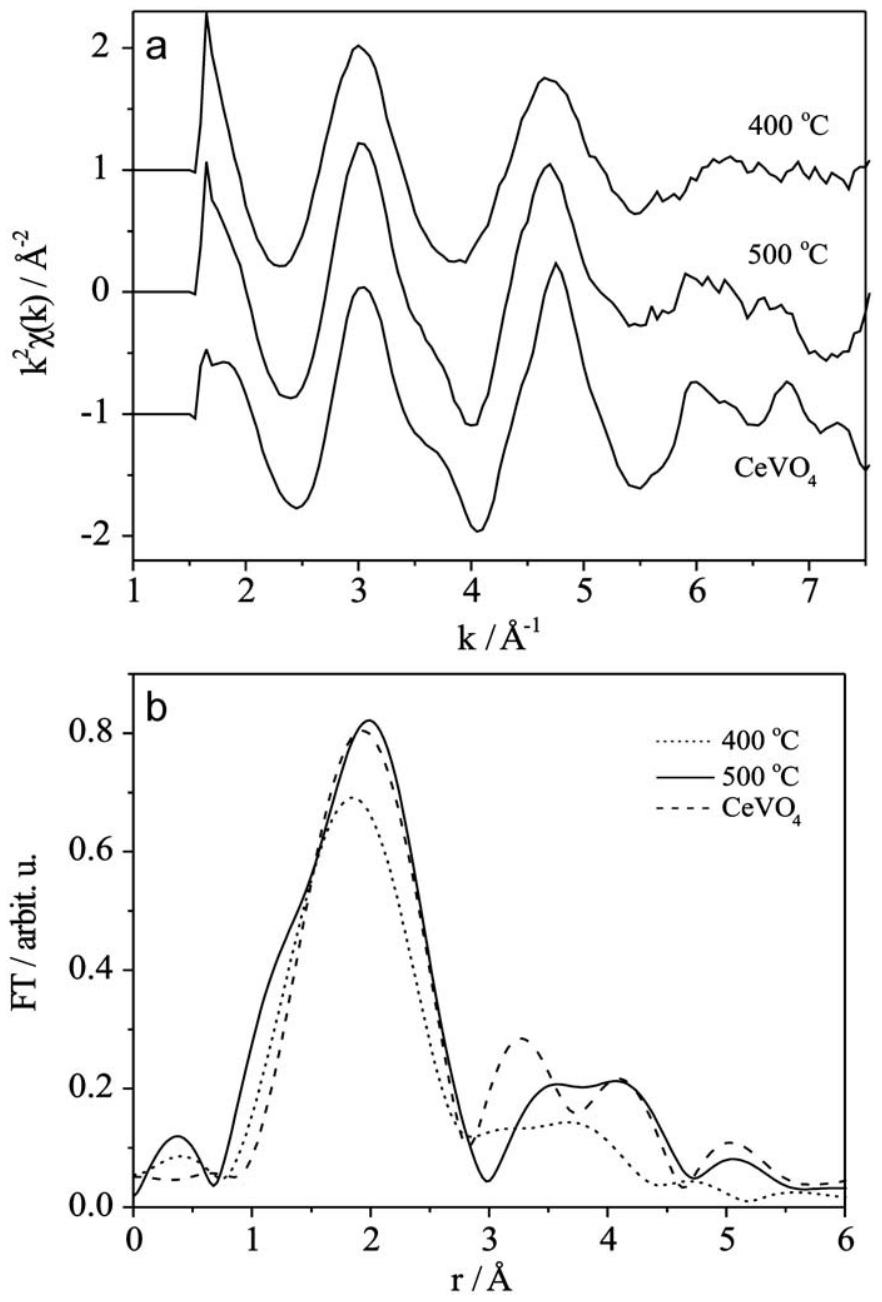

Fig. 9. EXAFS spectra of the films (b) $\left(400,500{ }^{\circ} \mathrm{C}\right)$ and standard $\mathrm{CeVO}_{4}$, in $k$-space (a) and $r$-space (b). Weighing $k^{2}, k=2.5-7.0 \AA^{-1}$ 
Table 1

Parameters of the best fit first shell EXAFS model for the spectra of the thin films and $\mathrm{CeVO}_{2}$ as a standard: $k=2.5-7.0 \AA^{-1}, r=1.5-2.5 \AA$, weighing $k^{2}, N_{1}=N_{2}=4$, $S_{0}^{2}=1, E_{0}=5 \mathrm{eV}$.

\begin{tabular}{llll}
\hline & $400{ }^{\circ} \mathrm{C}$ & $500{ }^{\circ} \mathrm{C}$ & $\mathrm{CeVO}_{4}$ \\
\hline$r_{1}[\AA]$ & $2.46(2)$ & $2.45(2)$ & $2.43(1)$ \\
$r_{2}[\AA]$ & $2.56(2)$ & $2.55(2)$ & $2.53(1)$ \\
$\sigma^{2}\left[\AA^{2}\right]$ & $0.017(3)$ & $0.013(3)$ & $0.013(2)$ \\
$r_{\text {fit }}$ & 0.015 & 0.014 & 0.005 \\
\hline
\end{tabular}

Uncertainties of the last digit are given in parenthesies.

process of crystallization toward the $\mathrm{CeVO}_{4}$ structure takes place between 400 and $500{ }^{\circ} \mathrm{C}$, resulting in complete formation of the first shell of neighbours at $500{ }^{\circ} \mathrm{C}$. Conceivably, the electrochemical properties of the material, the ion-storage capacity in our case, depend on the ordering of the atomic neighbourhoods.

\section{Conclusions}

$\mathrm{Ce} / \mathrm{V}$ mixed oxide thin films with $\mathrm{Ce} / \mathrm{V}$ molar ratio 1 were prepared by sol-gel process using $\mathrm{CeCl}_{3} \cdot 7 \mathrm{H}_{2} \mathrm{O}$ and $\mathrm{NH}_{4} \mathrm{VO}_{3}$ as precursors and methanol or distilled water as a solvent. The thin films prepared from distilled water (b) had higher ion-storage capacities than those prepared from methanol (a). Electrochemical characteristics were strongly dependent on the temperature and the duration of annealing. In thin films (b) heat-treated at $400{ }^{\circ} \mathrm{C}$, the ion-storage capacity was less than $1 \mathrm{mC} \mathrm{cm}^{-2}$ and EXAFS showed strong disorder in their structure. Films (b) annealed at $500{ }^{\circ} \mathrm{C}$ ( $40 \mathrm{~nm}$ thick) had ion-storage capacities $>20 \mathrm{mC} \mathrm{cm}^{-2}$, they were highly transparent except in near UV, where strong cathodic bleaching occurred. EXAFS analysis suggests that the ion-storage capacity correlates with the degree of crystallization: while the immediate neighbourhood of Ce ion exhibits the crystal structure of $\mathrm{CeVO}_{4}$ in films (b) (annealed at 400 and $500{ }^{\circ} \mathrm{C}$ ), the weaker heat-treatment leaves some static disorder even in the range of first neighbours. The incompletely formed oxygen shell of Ce atoms may hinder the storage of ions.

\section{Acknowledgements}

The authors gratefully acknowledge the Slovenian Research Agency for the financial support of the present study within the research programs P1-0134-0103 and P1-0112. This work was supported by DESY and the European Community under Contract RII3-CT-2004-506008 (IA-SFS). Provision of synchrotron radiation facilities by HASYLAB (project II-04-065 EC) is acknowledged. We would like to thank E. Welter of HASYLAB station E4 for expert advice on beamline operation.

\section{Appendix A. Supporting information}

Supplementary data associated with this article can be found in the online version at doi:10.1016/j.solmat.2009.11.023.

\section{References}

[1] K. Muthu Karuppasamy, A. Subrahmanyam, The electrochromic and photocatalytic properties of electron beam evaporated vanadium-doped tungsten oxide thin films, Sol. Energy Mater. Sol. Cells 92 (2008) 1322-1326.

[2] Y.-M. Li, T. Kudo, Properties of mixed-oxide $\mathrm{MoO}_{3} / \mathrm{V}_{2} \mathrm{O}_{5}$ electrochromic films coated from peroxo-polymolybdovanadate solutions, Sol. Energy Mater. Sol. Cell 39 (1995) 179-190.

[3] T. Ivanova, A. Harizanova, M. Surtchev, Z. Nenova, Investigation of sol-gel derived thin films of titanium dioxide doped with vanadium oxide, Sol. Energy Mater. Sol. Cells 76 (2003) 591-598.

[4] I. Kozjek Škofic, N. Bukovec, Improved ion-storage capacity of Ce-V mixed oxide films, Acta Chim. Slov. 49 (2002) 267-278.

[5] E.A. Souza, A.O. dos Santos, L.P Cardoso, M.H. Tabacniks, R. Landers, A. Gorenstein, Copper-vanadium mixed oxide thin film electrodes, J. Power Sources 162 (2006) 679-684.

[6] F. Artuso, F. Bonino, F. Decker, A. Lourenco, E. Masetti, Study of lithium diffusion in RF sputtered nickel-vanadium mixed oxides thin films, Electrochim. Acta 47 (2002) 2231-2238.

[7] P. Soudan, J.P. Pereira Ramos, J. Farcy, G. Gregoire, N. Baffier, Sol-gel chromium-vanadium mixed oxides as lithium insertion compounds, Solid State Ionics 135 (2000) 291-295.

[8] W. Chen, Y. Kaneko, N. Kinomura, Preparation and electrochromic properties of V-Nb mixed-oxide films by evaporation, J. Appl. Electrochem. 33 (2003) 515-518.

[9] F. Varsano, F. Decker, E. Masetti, F. Croce, Lithium diffusion in ceriumvanadium mixed oxide thin films: a systematic study, Electrochim. Acta 46 (2001) 2069-2075.

[10] Y. Kaneko, W. Chen, Electrochemical synthesis of electrochromic Ce-V oxide films in $\mathrm{NH}_{4} \mathrm{HSO}_{4}$ melts, J. Electroanal. Chem. 559 (2003) 87-90.

[11] C. Flamini, A. Ciccioli, A. Giardini, A. Mele, A thermodynamic study of laserinduced ablation of $\mathrm{ZrO}_{2}, \mathrm{CeO}_{2}, \mathrm{~V}_{2} \mathrm{O}_{5}$, and mixed $\mathrm{Ce}-\mathrm{V}$ oxides, J. Mater. Synth. Process. 9 (2001) 143-151.

[12] U. Opara Krašovec, B. Orel, A. Šurca, N. Bukovec, R. Reisfeld, Structural and spectroelectrochemical investigations of tetragonal $\mathrm{CeVO}_{4}$ and $\mathrm{Ce} / \mathrm{V}$-oxide sol-gel derived ion-storage films, Solid State Ionics 118 (1999) 195-214.

[13] Z. Crnjak Orel, New counter electrode prepared as vanadium oxide and V/Ce oxide films: preparation and characterization, Solid State Ionics 116 (1999) 105-116.

[14] I. Kozjek Škofic, S. Šturm, M. Čeh, N. Bukovec, $\mathrm{CeO}_{2}$ thin films obtained by sol-gel deposition and annealed in air or argon, Thin Solid Films 422 (2002) 170-175.

[15] R. Cerc Korošec, I. Kozjek Škofic, N. Bukovec, Influence of thermal treatment on the ion-storage capacity of $\mathrm{Ce}$ oxide and $\mathrm{Ce}-\mathrm{V}$ mixed oxide films, Thermochim. Acta 411 (2004) 211-217.

[16] J. Padežnik Gomilšek, I. Kozjek Škofic, N. Bukovec, A. Kodre, X-ray absorption study of $\mathrm{CeO}_{2}$ and $\mathrm{Ce} / \mathrm{V}$ mixed oxide thin films obtained by sol-gel deposition, Thin Solid Films 446 (2004) 117-123.

[17] J. Padežnik Gomilšek, A. Kodre, N. Bukovec, I. Kozjek Škofic, Atomic effects in EXAFS structural analysis of mixed Ce oxide thin films, Acta Chim. Slov. 51 (2004) 23-32.

[18] B. Ravel, M. Newville, ATHENA, ARTEMIS, HEPHAESTUS: data analysis for $\mathrm{X}$-ray absorption spectroscopy using IFEFFIT, J. Synchrotron Radiat. 12 (2005) 537-541.

[19] J.J. Rehr, J. Mustre de Leon, S.I. Zabinsky, R.C. Albers, Theoretical x-ray absorption fine structure standards, J. Am. Chem. Soc. 113 (1991) 5135-5140.

[20] C. Sigala, D. Guyomard, Y. Piffard, M. Tournoux, Synthesis and performances of new negative electrode materials for "rocking-chair" lithium batteries, CR Acad. Sci. Paris 320 (IIb) (1995) 523-529.

[21] F. Artuso, G. Picardi, F. Bonino, F. Decker, S. Bencic, A. Surca Vuk, U. Opara Krasovec, B. Orel, Fe-containing $\mathrm{CeVO}_{4}$ films as Li intercalation transparent counter-electrodes, Electrochim. Acta 46 (2001) 2077-2084.

[22] B.C. Chakoumakos, M.M. Abraham, L.A. Boatner, Crystal structure refinements of zircon-type $\mathrm{MVO}_{4}(\mathrm{M}=\mathrm{Sc}, \mathrm{Y}, \mathrm{Ce}, \mathrm{Pr}, \mathrm{Nd}, \mathrm{Tb}, \mathrm{Ho}, \mathrm{Er}, \mathrm{Tm}, \mathrm{Yb}, \mathrm{Lu})$, J. Solid State Chem. 109 (1994) 197-202. 